\title{
EVOLUTION OF SOCIALLY RESPONSIBLE MARKETING IN RUSSIAN SERVICE SECTOR
}

\author{
Oksana Barsova ${ }^{1}$
}

\begin{abstract}
Though evidence of socially responsible behavior of companies appeared to be indisputable, the most problematic for any company is to align it with the employed marketing strategy and enhance the opportunities it can provide for creating competitive advantage and further innovation. Corporate social initiatives are often disconnected and fragmented, which causes constraints to analyze their prospects to cut expenses and increase revenues. The statistical data of a period of over four years show the continual growth in Russian service sector which can provide resources for "world-positive" business initiatives. Though authorities traditionally and usually force the ways of engaging business in financing social programs, the image of a socially responsible and environmentally friendly business provides opportunities for a sustainable upturn in Russian service sector.
\end{abstract}

JEL Classification Numbers: M00, M14; DOI: http://dx.doi.org/10.12955/cbup.v5.895

Keywords: Corporate Social Responsibility (CSR), service sector, sustainable business, upturn.

\section{Introduction}

For the most of businesses, even operating internationally, it is impossible to work in isolation from society. Management realizes that marketing must create a socially responsible image as the "public face" of a company, especially in the service sector, which directly deals with its clientele. Though, both marketers and managers are aware that sustainable activities will not immediately increase sales or improve the company image. To bring a substantial effect on the intangible assets scale, having gained a strong reputation of a socially responsible business, companies need to pursue consistency in employing and promoting socially responsible programs.

The universal general trend mentioned by Skorobogatyih (2014) is dominating in social marketing over liberal methods in corporate social responsibility. The development of socially responsible marketing (SRM) appeared in opposition to the strategy focused on excessive consumerism and as an intrinsic response to business operations that caused environmental damages. The concept SRM itself is sometimes viewed as a constituent of Corporate Social Responsibility (CSR), its ambient extension. SRM constitutes abandonment of even legally accepted deceptive marketing practices in defining a marketing mix for any product or service.

The philosophy behind the concept is in balancing the aspiration of maximizing profit and ethical aspects of business activities and moral standards of society. Therefore, SRM can be defined as "an obligation of an organization's marketing management towards the welfare and interests of the society in which it operates." (Businessdictionary, 2017)

\section{Evaluating CSR impact}

Companies usually prefer to invest in short-term projects with high publicity as was illustrated by Taylor (2015). Long-term programs to ensure the social and economic development of a region do not have the same media coverage and seem to be less attractive. Following Ferrell and Hartline (2011), we can admit that sponsorship of some big event creates an immediate response and may result in remarkable improvement of a company's image.

Socially-oriented investments can be defined as forms of financial support allocated by business for implementing long-term programs, usually organized in the mode of cooperative partnership, objected at easing social tension in the area of a company operation and raising living standards for all groups of the population.

Primarily, companies develop strategies of investing in their personnel what is also supposed to present a marketing tool of promoting the business as socially responsible. Besides paying salaries, different perks, such as medical insurance, fitness, and training facilities are financed. Many SME (small and medium size enterprises) and large holdings representatives consider that an opportunity to have a job and salaries payment can already promote a socially responsible image. (Financial Times, 2016)

\footnotetext{
${ }^{1}$ Plekhanov Russian University of Economics, barsovw2@mail.ru
} 
Having provided their staff with merited living standard, a company may ponder over investments in a local society, which can provide resources for further development and expansion and is very important for their successful operations in the area (Fig.1). Undoubtedly, a business' degree of involvement in socially responsible projects depends on the affordability of required resources. Every company's marketing strategy should optimize the balance of investments in social programs and the company's profitability.

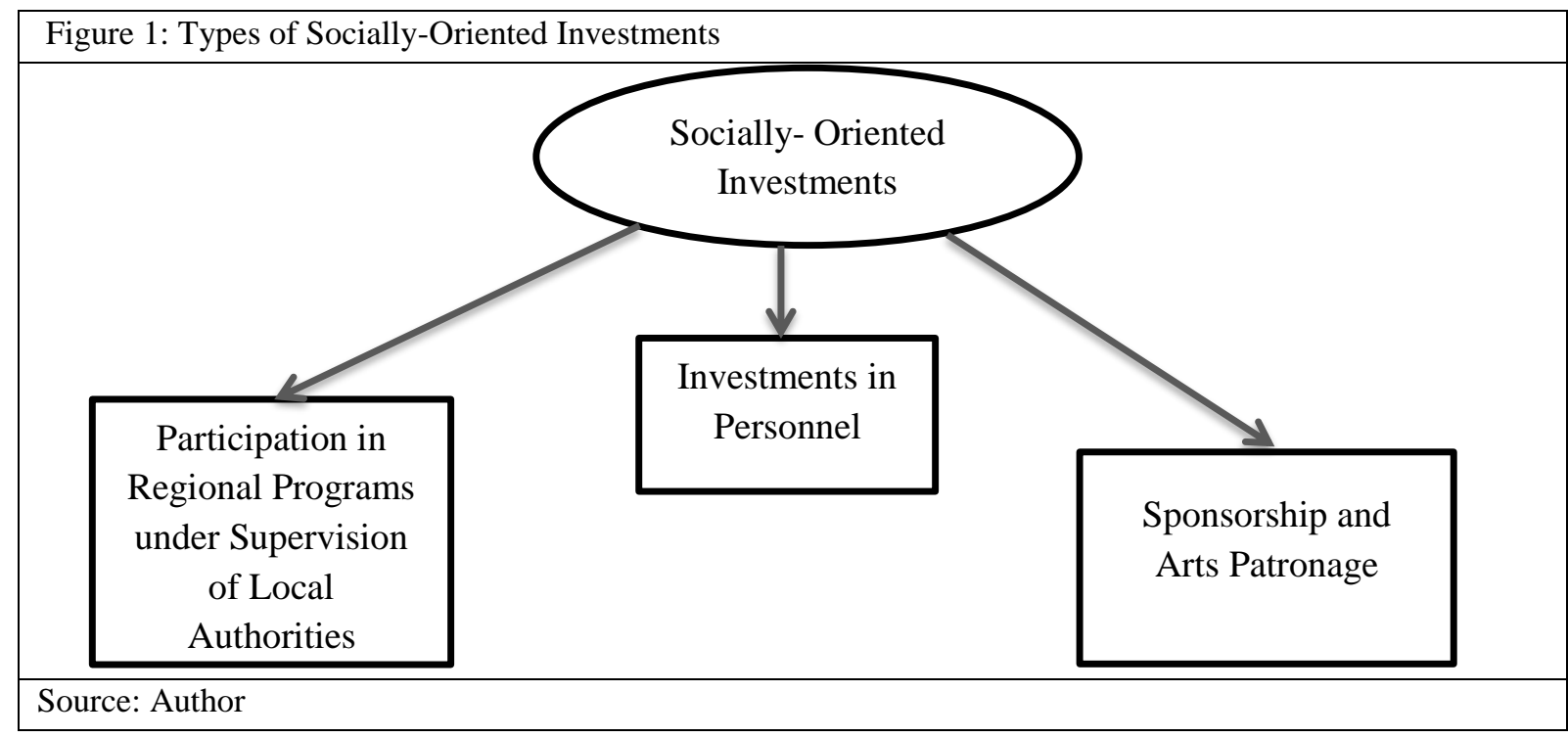

To expand studies made by Bonini et al. (2009) for marketers to improve scaling of sustainable business practices the following guidelines can be offered:

- the demand of consumers to be aware of the positive environmental and social impact (in this case they are ready to pay more for the goods and services);

- people working in companies pursuing socially responsible strategies are more committed and demonstrate better effectiveness;

- being engaged in socially and environmentally responsible activities helps businesses to enhance partnerships to retain market share and enter or develop new markets with stronger support;

- a company staff engaged in different CSR programs are reported to develop communication, collaboration, innovation and leadership skills;

- the reputation of a socially responsible business can improve access to capital as "Impact Investing" is increasingly supported by all types of financial institutions.

Besides all aspects mentioned above, there is also a moral imperative which seems to have no benefit for the bottom line. Although a going concern business may offer not only resources but expertise, leadership, and management to design the contingency strategy, that may lead to further development of company operations. A well-run business can easily mobilize the necessary resources and instantly channel the information or deliver assistance to the specific recipients or areas.

\section{CSR development in Russia}

In contrast to methodologically defined tendencies of corporate social responsibility (CSR) evolution in countries with developed economies, especially the USA by Armstrong and Kotler (2008), CSR in Russia is a relatively new marketing concept. The process of developing new approaches to interaction with society through being in trend with international tendencies, analyzed by Saginova et al. (2014), has peculiarities in establishing under the considerable government supervision as was emphasized by Karpova (2014). While business through CSR activity realizes its corporate interests, the state tends to integrate the socially responsible projects of companies in government social policy through stimulation and active involvement of companies both locally and nationally.

In Russia business is historically seen by government officials as a dependent and temporary source of raising capital for co-financing sustainable projects, as was stated by Novatorov (2015). Despite the very complicated current economic situation in Russia, investments in socially responsible projects, 
especially regionally, may at this stage - as never before - contribute to further capitalization and promote the image of a socially responsible company - a long-term strategic partner of social development policy.

The lack of institutional norms for CSR in the Russian Federation has logically been derived from prerevolutionary forms of philanthropy and charity and the system of social support in the Soviet period when all programs were initiated and totally controlled by the state, as was stated by Novatorov (2015). Following the period of privatization and prompt accrual of funds by some entrepreneurs resulted in firm distrust of citizens towards the level of justice in government-vs-business relationships. Moreover, social inequality and fierce stratification of the society has not contributed to generating loyal citizenry in our country. Till now the rate of our country's integration in the world informational systems and, especially with the economic sanctions from the European Union and the USA, in the world economy through unstable interaction channels and necessity to employ flexible tactics is very low. Besides, the absence of traditional corporate governance is intensified by the poor state of infrastructure.

Regarding legislation improvements to formalize integration of the Russian Federation in the international CSR programs the following highlights might be mentioned:

- the foundation of the Russian Union of Industrialists and Entrepreneurs (RSPP) - 1991

- RSPP initiated a set of programs in socially responsible field, among which was establishment of the Charter of Corporate and Business Ethics (2002)

- the Social Charter of Russian Business adoption by the Congress in 2004 with amendments of 2008

- the Anti-Corruption Charter of Russian Business was promulgated by RSPP in September 2012 at the summit with the country's prime minister

- following the appointment of Entrepreneurs' Rights Ombudsman (June 2012) the president of the Russian Federation, introduced an ombudsman's office for Russian national business in (December 2012)

- RSPP headed the process of B20 at the term of Russia chairing G20

Since 2014 introduction of new sanctions and strengthening complications, in spite of remaining influence of Russian governance and economic development in the world economy, most of the integration was transferred to the East. As for further participation in international associations in CSR activities, RSPP, for example, continues cooperation as an observer.

Markit Economics survey reveals extensive growth in Russia's service sector by July 2014. The Purchasing Managers' Index (PMI) for the upturn in the sector reached 55 points, the highest results for the previous 40 months. Analysts stated considerable increase of employment in the service sector, especially noted in hotel, restaurant and retail industries as a reimbursement of it in manufacturing and finance sectors. In May 2016 a survey of 300 firms indicated sustainable expansion in employment, sales and a range of other factors of service providers in Russia: Markit's index was 54.2 in April reflecting the improvement in demand. (HIS, 2016). By December 2016 Russia Composite Output Index rose to the highest level of 56.6 within 50 months, alongside with the stabilization of the workforce figures and marginal growth in selling prices of service providers (RT, 2016).

Analyzing the dynamics of overall reported data, all areas of business activity demonstrate steady growth. In particular, Russian retail, railway, professional services and airline sectors have strong positions in comparison with other world countries, according to Organisation for Economic Cooperation and Development (OECD) reports. (OECD.org., 2016)

Some other peculiarities of socially responsible behavior rooting historically in the "soul impulse" transformed into voluntary aid, organized as a spontaneous response to natural or social catastrophes. This type can be qualified as collective social help without any particular company, fund or state guidance, and governance. Or these initiatives can be regarded as CSR uniting people of some universities, institutions or enterprises if organized under the patronage of companies or legal authorities. Spontaneous donations of goods and money for people in Syria or Donbass may be a good example. These volunteer initiatives, especially in contingency situations, emerge a sense of social responsibility, uniting people's reaction to tragedy: "who else would help?" 
Political scientists believed that Russian model of social responsibility was based on "informal and often not transparent interaction between large corporations and government authorities." However, it should be admitted that nowadays the process of transition from bargaining practices to formalizing business liaising with government officials, the switch to the mutually beneficial partnership, though mostly regionally, is strongly developing. At federal level, sustainable business efforts are evaluated by the state authorities and supported by necessary legislation reforms. Regionally local power clearly aims at involving enterprises in solving social problems in the area to expand opportunities for implementing programs in social and economic spheres not only at the expense of companies' resources but in co-financed programs with federal and local budgets.

\section{Conclusion}

Even before the economic downturn, not many companies in service industry have considered investments in long-term socially-oriented programs as a marketing strategy leading to a substantial increase in an enterprise's compatibility and capitalization (intangible assets). In current conditions of service-oriented economy alongside with the economic sanctions towards the Russian Federation from Western countries, a persistent upturn in service sector's indicators can be stated. Although there is a tendency of curtailment of some socially-oriented programs by businesses in connection with focusing mainly on cost effectiveness and profitability, it can be noted that they become better targeted in crisis periods, especially at local levels.

\section{References}

Armstrong, G., \& Kotler P. (2008). Principles of Marketing. 12th ed. Upper Saddle River, NJ: Pearson Education, Inc.

Bonini, S. Koller, T.M. \& Mirvis P.H. (2009, July). Valuing social responsibility programs. McKinsey Quarterly. Retrieved from http://www.mckinsey.com/business-functions/strategy-and-corporate-finance/our-insights/valuing-social-responsibilityprograms

Businessdictionary. (2017). Social Responsibility. http://www.businessdictionary.com/definition/social-responsibility.html [Retrieved January 15, 2017]

Ferrell, O. C., and Michael D. Hartline (2011). Marketing strategy. Mason, OH: South-Western Cengage Learning.

Financial Times. (2016, May 5). Retrieved January 12, 2017 from https://www.ft.com/content/a0a7dae7-f095-39b9-817e$035 \mathrm{~b} 289 \mathrm{dc} 46 \mathrm{a}$

HIS Markit press release (2016). Retrieved from

https://www.markiteconomics.com/Survey/PressRelease.mvc/7b1c7c0b4e444c6f89b0b1a6a7aae4b6

Karpova V.S. (2014), Marketing i sovremennost [Marketing and Contemporaneity]. Monografiya pod obschey redaktsiey d.e.n., prof., Karpovoy V.S. Moskva, Vuzovskiy uchebnik Infra-M, 267 s., ISBN: 978-5-9558-0361-6. (UDK 339.1 (075.4), BBK 65.290-2, M 25).

Novatorov V.E. (2015). Sotsialno-kulturnyiy marketing: istoriya, teoriya, tehnologiya [Socio-cultural marketing: history, theory and technology]. «Lan», St. Petersburg. ISBN: 7196-1113-4.

OECD.org. Economic Policy Reforms: Going for Growth (2016). Retrieved from http://www.oecd.org/economy/goingforgrowth.htm

RT (2016) Russian service sector surge tops expectations. Retrieved from https://www.rt.com/business/354479-russiaservice-pmi-highest/

Saginova O.V., Skorobogatykh I.I., Musatova Z.B. (2014, November) Hidden Champions in Russia: Using Western Research Methodology to Study Dynamically Developing Markets. Life Science Journal. 2014 (5), 512-518. Life Science Journal, ISSN: 1097-8135.

Skorobogatyih I.I. (2014). Evolyutsiya marketinga v mire i v Rossii [Marketing Evolution in the World and in Russia]. Plekhanov Russian University of Economics, 9 (75), 97-113. Published by "Grebennikov" publishing house, Russia:Moscow. ISSN: 2074-5095.

Taylor N. F. (2015, July 1) 22 Great Examples of Socially Responsible Businesses. Business news daily. Retrieved from http://www.businessnewsdaily.com/5499-examples-socially-responsible-businesses.html 